\title{
旭川祇園地区における経年変化を考慮した 礫河原再生効果の検討 EVALUATION OF GRAVEL BAR RESTORATION CONSIDERING SECULAR CHANGE AT THE GION AREA IN THE ASAHI RIVER
}

\author{
前野詩朗 ${ }^{1} \cdot$ 吉田圭介 ${ }^{2} \cdot$ 平井康隆 ${ }^{3} \cdot{\text { 岩城智大 }{ }^{4} \cdot \text { 山口華穂 }}^{5} \cdot$ 藤田駿佑 $^{4}$ \\ Shiro MAENO, Keisuke YOSHIDA, Yasutaka HIRAI, Tomohiro IWAKI, \\ Kaho YAMAGUCHI and Syunsuke FUJITA
}

\begin{abstract}
1 フェロー会員 博士(工) 岡山大学大学院教授 環境生命科学研究科（†700-8530 岡山市北区津島中 3-1-1） 2 正会員 博士(工) 岡山大学大学院准教授 環境生命科学研究科（同上）

3 正会員 修士(工) 株式会社 建設技術研究所 九州支社 河川部（广810-0041 福岡市中央区大名 2-4-12） 4 学生会員 岡山大学大学院環境生命科学研究科 社会基盤環境学専攻（干700-8530 岡山市北区津島中 3-1-1） 5 学生会員 岡山大学環境理工学部 環境デザイン工学科（同上）
\end{abstract}

\begin{abstract}
Forestation on the bars in the middle reaches of the Asahi River has fairly progressed in recent years. The forestation reduces flood flow capacity and increases the water level during flooding. As countermeasure works of the forestation, tree's trimming and removal of deposited sand were conducted at the bar of the Gion area. Although the restored gravel bar was maintained for several years, reforestation has been confirmed there. In this study, the effect of a combination of two countermeasure works as sand removal of the bar and backfilling sand of low-water channel was evaluated using annual scale flood flow analysis over the next several years. Numerical results show that the the combination of works is more effective against the reforestation.
\end{abstract}

Key Words : Elevation change, forestation, gravel bar restoration, excavation of channel

\section{1.はじめに}

近年，全国の多くの河川で砂州の急速な樹林化が 問題となっている. 本研究で対象としている旭川も, 1980 年代以降, 砂州の樹林化が著しく進行し, 砶河 原が減少している。そのため，旭川を管理する国土 交通省は 2004 年 3 月に大原試験区，2005 年 3 月に 祇園試験区で，試験的に砂州上の植生伐採と砂州の 切り下げを実施した（図-1). その後, 大原試験区で は渡辺ら吕によって, 整備後の調査, 分析が行われて おり, その結果, 切り下げ箇所で $2 \sim 3$ 年程度で植生 の再繁茂が確認された。一方祇園試験区では，数年 にわたって動的な礫河原が維持されたが，その後に 大きな洪水がなかったため，2015 年現在，両試験区 ともに砂州の河岸沿いで植生が再繁茂している（写 真-1). また，鬼怒川や加古川でも，碟河原の再生や 樹林化の抑制を目的とし, 切り下げの試験施工が実 施されている2),3). しかし，旭川同様，施工箇所の一 部では植生の再繁茂が確認されている。このように 植生が再繁茂した箇所については，伐採等の人為的 な管理が必要となる。しかし，伐採を繰り返し行う には多大な労力と費用が掛かるため，なる心゙く一度 の施工によって, 自律的に碩河原が回復・維持され,
樹林化が抑制されることが望ましい.

以上の背景を考慮して，近年では，樹林化抑制や 礫河原再生策として, 砂州の切り下げに加えて他の 施工を組み合わせた工法が提案されている. 例えば, 阿河ら ${ }^{4)}$ は, 高水敷の切り下げと間伐の組み合わせに よって維持管理の省力化を検討した，長田ら5)は，砂 州切り下げと低水路の埋戻しに加えて, 高水敷を造 る組夕合わせにより，治水上問題の無い河道条件下 での樹林化抑制効果を検討した。また，八木澤ら 6) は，切り下げ，埋戻しを含めたいくつかのパターン を初期地形条件として 30 年間の植生動態解析を行 い, 各ケースが樹林化期待值に及ぼす影響を比較し, 切り下げのみの場合の方が効果が大きいことを示し た。これらの研究により対策工の組み合わせによる 樹林化抑制の有効性等が確認されているが，硯河原 再生箇所が, その後の土砂の堆積や植生の繁茂等で 施工前の状態にどの程度の期間で戻るかどうかにつ いては検討されていないのが現状である. 施工の長 期的な効果を評価するためには，少なくとも数年に わたる洪水による河床変動や植生の入植状況の変化 についても考慮する必要がある.

そこで本研究では，大原試験区の上流側の砂州に は車の乗り入れによる人為的影響が少なからずある 


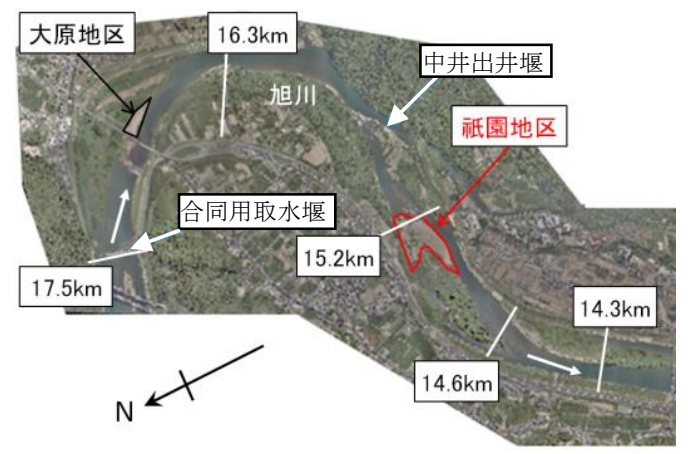

図-1 対象河道

ため，人為的影響のない祇園地区を対象に，写真-1 の現在を初期条件として砂州の切り下げと低水路の 埋戻しを組み合わせた 3 つの地形ケースについて今 後 5 年間年平均最大流量 $\left(1000 \mathrm{~m}^{3} / \mathrm{s}\right)$ 規模の洪水が 毎年 1 回来ることを想定し, 植生消長シミュレーシ ヨンを行った．具体的には，まず平面 2 次元河床変 動モデルにより得られる砂州上の 2015 年の無次元 掃流力を計算した後, 植生消長モデルによって, 洪 水後の 1 年間の植生繁茂状況を解析した。得られた 結果を 2 年目の地形と植生の初期条件として同規模 の洪水を発生させて河床変動解析を行った。これを 5 年分行った後, 施工箇所の無次元掃流力と河床変 動，植生繁茂状況の結果から，施工の持続性につい ても検討した。

\section{2. 対象河道の概要}

本研究では，岡山市を流れる一級河川旭川を対象 とした，図-1に示すように，祇園地区は旭川河口か ら約 $14.6 \mathrm{~km} \sim 15.2 \mathrm{~km}$ 間の中州に位置している．解析 では祇園地区を含むように河口から $14.3 \mathrm{~km} \sim 16.3 \mathrm{~km}$ の区間で解析を行った。各区間の河道幅は約 $300 \mathrm{~m}$, 平均河床勾配は $1 / 670$, 河床材料の平均粒径は $30 \mathrm{~mm}$ 程度である。

著者らは祇園地区で 2008 年から 2010 年，2013 年 から 2015 年まで，木本類・草本類を対象とした植生 調査, 砂州上の河床変動調査, 河床粒径調查を行っ ており，本解析における河床材料の粒度分布や植生 消長モデルに反映している.

\section{3. 解析概要}

\section{（1）解析モデル}

解析には河川の流れ・河床変動解析ソフトウェア であるiRICに含まれている平面二次元ソルバーの Nays2DHを用いた。本研究では, 河床変動解析で混 合粒径を取り扱うため, 河岸侵食は考慮していない. また，河床変動解析は掃流砂の夕を考慮し，渡邊の 式7)を用いた，植生抵抗は，植生の抗力係数と単位体 積に占める植生の遮断面積, 植生高を用いて計算し
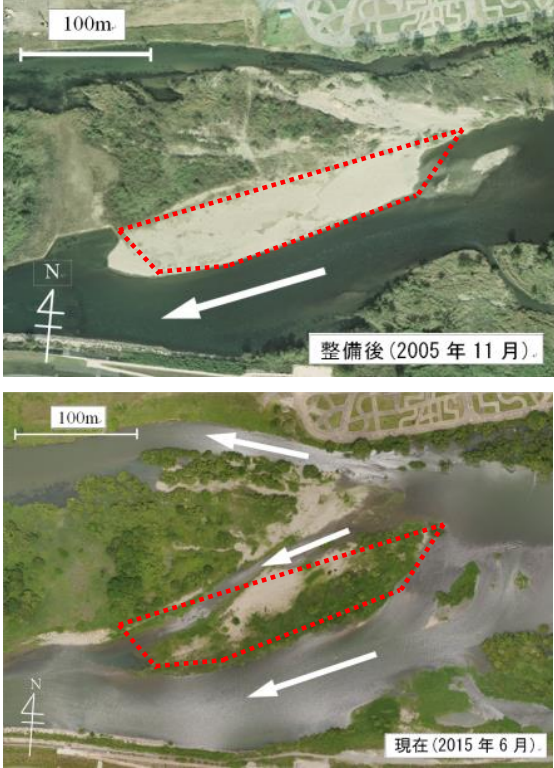

写真-1 祇園試験区の整備後の最初の洪水後と現在の様子 （赤点線：磁河原再生箇所）

ている．なお，ここで用いる抗力係数は 1.0 と，植 生の倒伏を考慮するため, 倒伏状態に応じて植生高と 遮断面積を適宜変更している. 交換層の厚さは低水路 の $D_{90}$ 粒径の3倍の值 $(0.3 \mathrm{~m})$ を与えた ${ }^{8)}$.

植生消長モデルについては, 前野ら孚が提案したモ デルを用いた。このモデルは，iRICによる解析で得ら れた流速, 河床変動量などの結果を用いて, 植生の流 失，倒伏の判定を行い，植生種や平水位との比高差， 河床の維持年数等の関係から, 植生の成長と入植の計 算ができるものである.これらの条件は現地調査の結 果と, 末次ら ${ }^{10)}$, 渡辺ら ${ }^{1)}$ の知見を基に設定している。 また, 植生は倒伏する草本群落と倒伏しない木本群落 に区分しており, 倒伏樹木からの再萌芽は考慮してい ない. なお，植生の入植条件については一部モデルの 改良を行った．既往のモデルでは，河床の維持年数6 年目で，水際以外の比高差 $2 \mathrm{~m}$ 以内の箇所に，ツルョ シに代りヤナギが入植するが, 祇園地区の現地調査結 果から，中ナギの入植を考慮していない.

本研究では，5年間繰り返し河床変動解析を行うこ とから，上記の考えを基に，植生抵抗の值を毎年更新 するものとした。

Nays2DHへの適用性については, 2011年（ピーク流 量 $3403 \mathrm{~m}^{3} / \mathrm{s}$ ）と2013年（ピーク流量 $1884 \mathrm{~m}^{3} / \mathrm{s}$ ）に発生 した既往洪水を対象に解析を行い, 水位は概旅観測值 を再現できている.また, 河床変動量は, 洪水前後の 現地調查データがある2013年洪水を対象に比較を行 い, 砂州上において洪水後の河床高が概ね再現できて いることを確認した。

\section{（2）対象洪水}

本研究では, 年平均最大流量 $1000 \mathrm{~m}^{3} / \mathrm{s}$ 規模の洪水 を対象とした。これは, 年 1 回程度発生する洪水によ って砂州上の河床擋乱が生じれば, 砂州上の樹林化抑 制に効果があると考えたためである。そこで，近年旭 


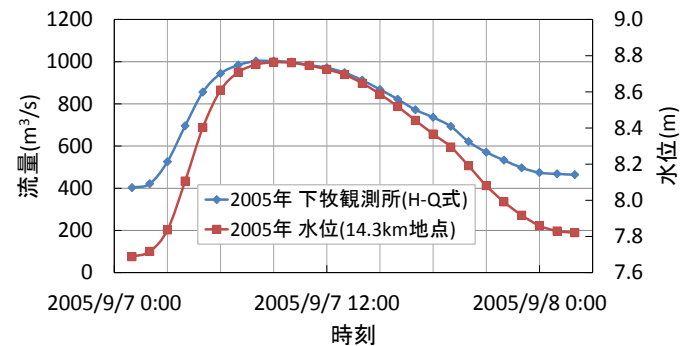

図-2 流量ハイドログラフと水位 (2005 年 下牧観測所)

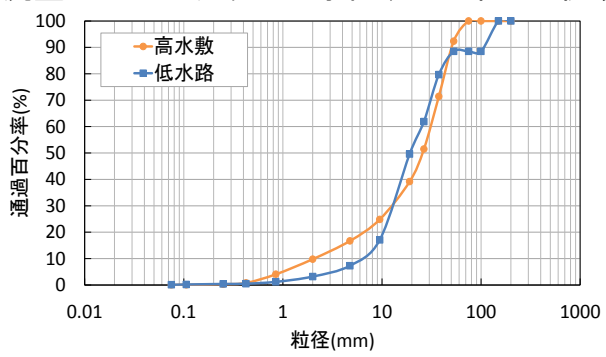

図-3 解析に使用した粒度分布

川で発生した洪水の中で, 対象洪水規模に近い 2005 年 9 月の洪水（ピーク流量 $1003 \mathrm{~m}^{3} / \mathrm{s}$ ）のハイドログ ラフデータを解析に用いた。解析対象時間は 26 時間 である. H-Q 式に基づく下牧観測所(河口から $19.0 \mathrm{~km}$ 地点）の流量ハイドログラフと解析区間下流端の $14.3 \mathrm{~km}$ 地点の水位を図-2 に示す.

\section{（3）解析条件}

解析格子は，縦断方向に189分割，横断方向に57分 割した。メッシュの格子間隔は約 $10 \mathrm{~m}$ である.

境界条件については，上流端流量は，下牧観測所 での前述の流量八イドログラフを用いた。また，下 流端水位は, 河口から $11.6 \mathrm{~km} \sim 17.5 \mathrm{~km}$ の区間で, 三野 観測所（河口から $11.6 \mathrm{~km}$ 地点）の観測値を下流端水 位に与えた解析を行い，その結果から，14.3km地点 の水位を与えた。

河床高は、2013年に行われた縦断200m間隔の定期 横断測量のデータを内挿し, さらに祇園地区につい ては2015年6月に実施したドローンによる写真測量 データを用いて砂州の地形を修正した.

粒度分布は，低水路では，2013年に行われた岡山 河川事務所の河床材料調查結果を用いた。 高水敷で は中州の河床材料のデータがなかったため, 著者ら が行っている現地調査で採取した河床材料の粒度分 布（2015年）を用いた。それぞれの粒度分布は図-3 に示す。 また, 埋戻し箇所は低水路の最大粒径 （125mm）を一様に与えた。

地被抵抗は，マニング式で扱い，低水路のマニン グ係数の值を $0.028 \mathrm{~m}^{-1 / 3} \mathrm{~s}$, 高水敷のそれを $0.026 \mathrm{~m}^{-1 / 3} \mathrm{~s}$ とした。これらの值は前野ら ${ }^{11)}$ の研究例を参考にし た. また, 埋戻し箇所では表層の粒径を低水路の最 大粒径 $(125 \mathrm{~mm})$ に設定したため, Manning-Strickler ${ }^{12)}$ の式より, $0.031 \mathrm{~m}^{-1 / 3} \mathrm{~s}$ とした.

植生データは, 吉田ら ${ }^{13)}$ が植生消長モデルを用い て得た2013年の植生分布を基に, 2015年6月に撮影さ

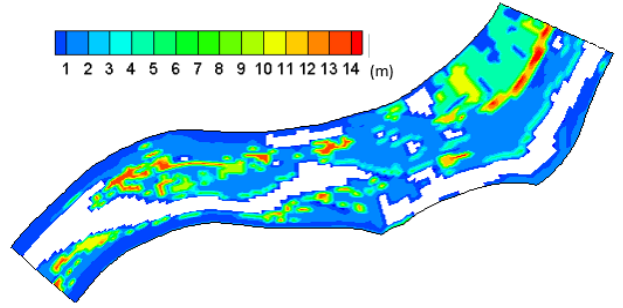

(a) 植生高

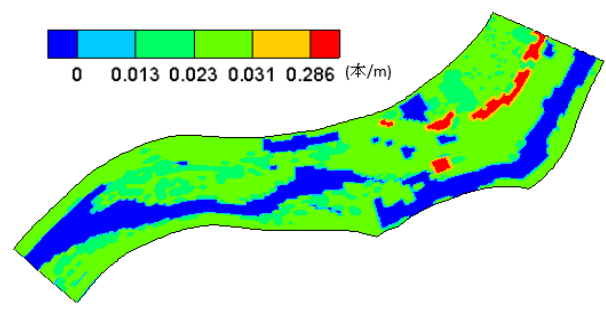

(b) 密生度

図-4 解析に用いた植生分布図

れた航空写真データを用いて修正した。 その際，人為 的な植生伐採の影響は考慮できないため, 岡山河川事 務所より情報を得て, 適宜, 植生分布データを修正し た. 得られた植生データについては現地で確認した結 果, 概ね植生高や植生密度が一致していた。 図-4に表 -1のCase1の解析で用いた植生データを示す.

(4) 解析ケースの説明

（a）切り下げ，埋戻しの方針

本研究では, 以下の3つの方針を基に切り下げ量, 埋戻し量を設定した。(1)河積は増減しないようにす る. (2)今後の洪水によって低水路の河床低下が生じな いよう, 埋戻し箇所には低水路の最大粒径を与える. (3)切り下げ箇所が平水時に冠水しないようにする.

\section{(b) 解析ケースの設定}

表-1に示寸通り，切り下げ，埋戻し，植生伐採を組 み合わせた3つのケースを設定した。Case1は現況地 形, Case2は中州中央を切り下げた地形である. 図-5 に切り下げ, 埋戻しの箇所, 図-6に切り下げ箇所縦断 図（図-5の赤枠内の橙色のライン）と，各ケースの $15.0 \mathrm{~km}$ 地点の横断図を示寸. 左岸側の低水路に集中し ていた流れを解消するために, 図-5の黄線の枠で囲ま れた箇所においては必ず伐採と河床高 $8.0 \mathrm{~m}$ (平水時に 冠水しない高さ）までの切り下げを行った. また, $14.8 \mathrm{~km}$ 地点の掘削箇所左岸側に低水路の一部が入り 込んでいたため,ここから掘削路内の流れが分断され る傾向が見られた。これにより，この地点から下流側 での掘削路の掃流力の低下が懸念されたため,この箇 所でも一部埋戻しを行った. 各ケースで対象洪水を発 生させ, 砂州上で生じた河床変動を比較して対策工の 効果について検討した. また, 植生消長モデルで洪水 後の地形の植生繁茂状況を再現し, 翌年の地形の初期 条件として同規模の洪水を発生させた.このサイクル を5年分行い, 施工箇所の河床変動と植生繁茂状況の 結果から，礫河原の持続性を評価した。 
表-1 解析ケース

\begin{tabular}{|l|c|c|c|c|c|}
\hline & 切り下げ & 埋め戻し & 植生伐採 & 方針適用 & 備考 \\
\hline Case1 & $\times$ & $\times$ & $\times$ & - & 現況地形 \\
\hline Case2-1 & 0 & $\times$ & 0 & (3) & \multirow{2}{*}{ 中州中央切り下げ } \\
\hline Case2-2 & 0 & 0 & 0 & (1) (3) & O \\
\hline
\end{tabular}

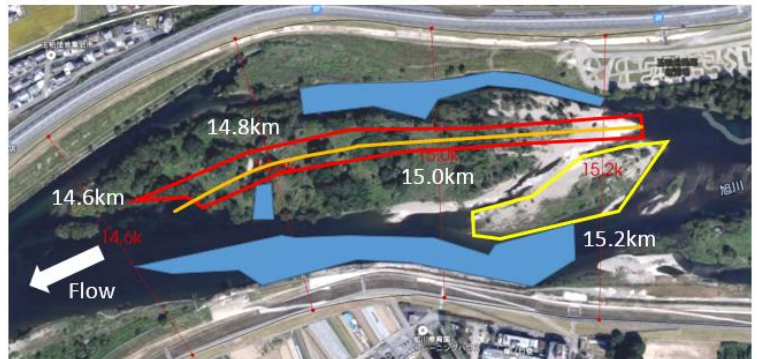

図-5 祇園地区＼cjkstart切り下げ (赤), 埋戻し（青）箇所 掘削路縱断ライン(橙)

\section{4. 解析結果と考察}

\section{(1) Case1の解析結果}

図-7に現況河道におけるピーク流量時の流速と水 深の平面図を示す。この図を見ると，中州の左岸側 に流れが集中していることが分かる。また，ピーク 流量時においても中州上の冠水深は小さく, 流速も 小さく一様でない. 以上から, 現況河道のままでは, 今後, 年平均最大流量規模の洪水では, 植生を流出 させることが難しく，砂州上に細粒土砂が堆積し更 なる樹林化が懸念される.

\section{（2）切り下げ，埋戻し効果の検討}

切り下げと埋戻し効果を無次元掃流力の比較によ つて検討する．なお、ここで検討する無次元掃流力 は，85\%粒径における值としている9)。これは，前述 の植生消長シミュレーションモデルにおいて，85\% 粒径における無次元掃流力が無次元限界掃流力を上 回ったと同時に，植生高と河床変動量に応じて植生 の消失や倒伏の判定を行うためである。なお，本研 究における無次元限界掃流力は, 使用した粒度分布 を基にEgiazaroff式によって導いた值である0.04を用 いた。また，現地調查の結果から，河床変動が発生 していない箇所でも植生の倒伏が見られたことか ら，田中・佐々木の抗力モーメントの式 ${ }^{14) を}$ 用いた 植生の倒伏判定も別途行っている.

図-8, 図-9には各々, 掘削路縦断ライン上と $15.0 \mathrm{~km}$ における横断ライン上の無次元掃流力を示した.

まず，図-8を見ると，植生伐採と，切り下げを行 ったCase2-1では, 無次元掃流力が大幅に上昇したも のの，450mから下流側において無次元掃流力が 0.04 を上回ることはなかった。一方，切り下げに加えて 左右岸の低水路を埋戻したCase2-2では, 縦断ライン 上のほとんどで無次元掃流力が $0.04 を$ 超えており， 掘削路内一の植生入植を防ぐことが出来ると考えら れる。これは，低水路を埋戻したことによって，左 岸に集中していた流れが高水敷に乗り上げやすくな ったことが原因と言える.

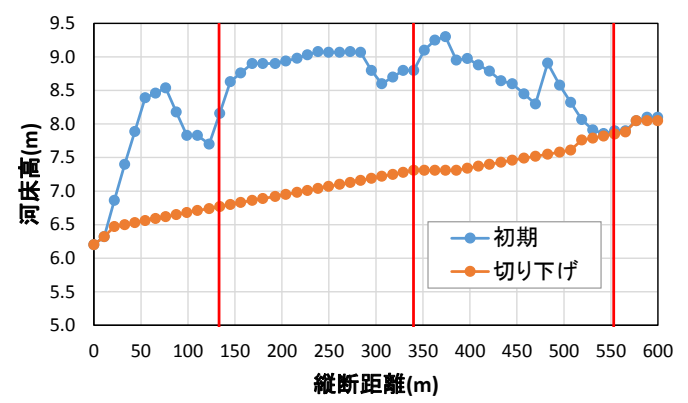

（a）祇園地区切り下げ箇所縦断図 (0m 地点が下流側)

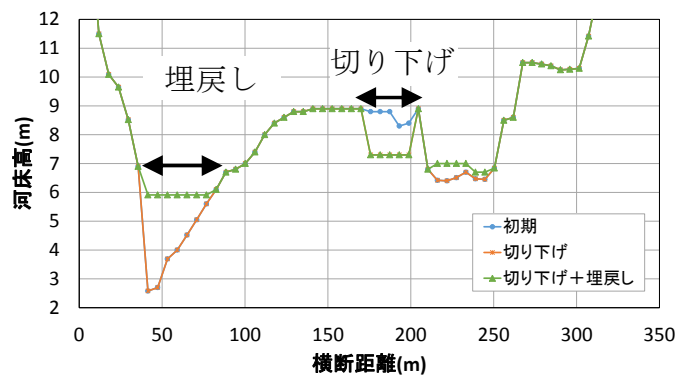

(b) 祇園地区 $15.0 \mathrm{~km}$ 横断図

図-6＼cjkstart切り下げ，埋戻し縱横断図

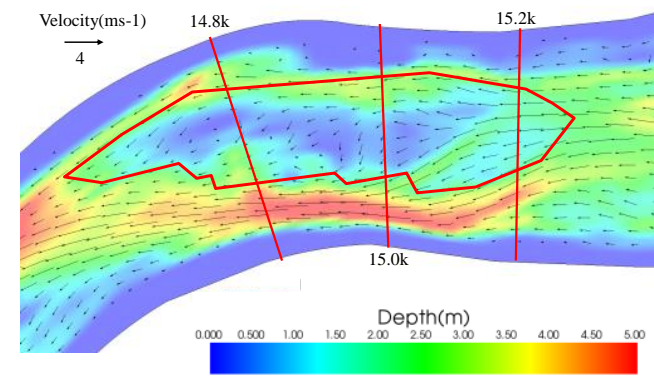

図-7 Case1 流速-水深（赤枠が祇園地区砂州）

次に，図-9を見ると，Case2-1はCase1と比べ，左右 岸の低水路で掃流力が低下し，掘削箇所で大幅な上 昇が確認された。 また, Case2-2ではCase2-1と比べて 低水路での掃流力が上昇しているが，これは，埋戻 しによって水深が浅くなり，それに伴い流速が上昇 したことが原因と考えられる，さらに，Case2-2では 横断距離 100 130m付近で掃流力が大幅に上昇して いることが確認された。これは左岸側の埋戻しによ って洪水流が高水敷に乗り上げ易くなったことが原 因と言える。これによって, 大規模な洪水が発生し た際に，掘削路以外の箇所でも植生が流出する可能 性があると考えられる。

以上の点から, 切り下げに加えて埋戻しを行うこと で, 掘削路内で無次元掃流力が増加し，より高い樹 林化抑制効果が得られると言える.

\section{(3) 碟河原の持続性の検討}

Case2-1, Case2-2において, 年平均最大流量規模の 洪水を5回発生させ, 掘削路が維持されるかどうかを 河床変動量と, 植生入植の観点から検討寸る.

まず，河床変動に関する考察を行う．図-10に掘削 路の下流端を起点とした掘削路縦断ラインにおける 


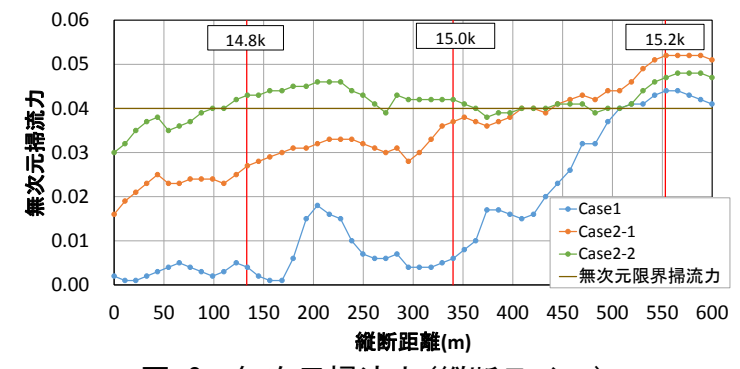

図-8 無次元掃流力 (縦断ライン)

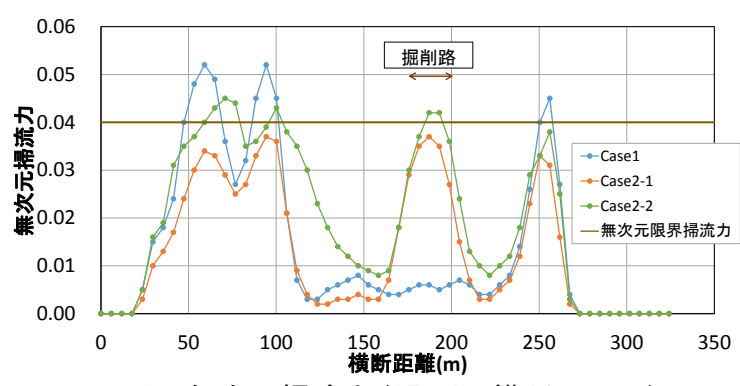

図-9 無次元掃流力 (15. 0km 横断ライン)

Case2-2の河床高の経年変化とCase2-1の最終年の結 果を示す．また，図-11にCase2-2の前年と比較した 河床変動量の経年変化とCase2-1の最終年のそれを 示す. 図-10を見ると，両ケースとも掘削路上流側で 洗掘傾向, 下流側で堆積傾向である。これは, 上流 側で洗掘された土砂が徐々に下流側に流されている からであると考えられる．5年目終了時点を見ると Case2-1では掘削路の400mより下流の大部分で堆積 しており，Case2-2の切り下げと埋め戻しを組み合わ せた方が掘削箇所の礫河原が維持されや寸いことが 分かる、また, 図-11を見ると, いずれも縦断ライン 上において洗掘と堆積が交互に発生しているが Case2-2の方が各年の洗掘堆積量が多いことが分かる.

次に，植生入植に関しての考察を行う。図-12に Case2-2の縦断ライン上の無次元掃流力の経年変化 とCase2-1の最終年の結果を示す。これを見ると，

Case2-1の5年目では150mより下流側において掃流力 が無次元限界掃流力 0.04 を下回っている。一方, Case2-2では，いずれの年においても上下流端を除い て縦断ラインのほとんどの範囲で無次元限界掃流力 を超えていることが分かる．以上から，切り下げに 加えて埋め戻しを行うと掘削路が維持されやすいと 考えられる.また, 図-13, 図-14にCase2-1と2-2の最 終年の植生高を示す．これを見ると，いずれのケー スにおいても掘削路内に植生が入植することはなか ったが，切り下げなかった砂州上で図の破線で示す ように若干の違いが見られた。植生流失効果の大き い方を赤色，小さい方を黒色で示している． $15.2 \mathrm{~km}$ の掘削路の左岸寄りでCase2-2で植生の入植が確認 された以外は，若干ではあるがCase2-2の方が良好な 結果が得られた。

以上のように植生繁茂抑制についてはCase2-2の 方が若干よくなるが大きな違いは見られなかった.

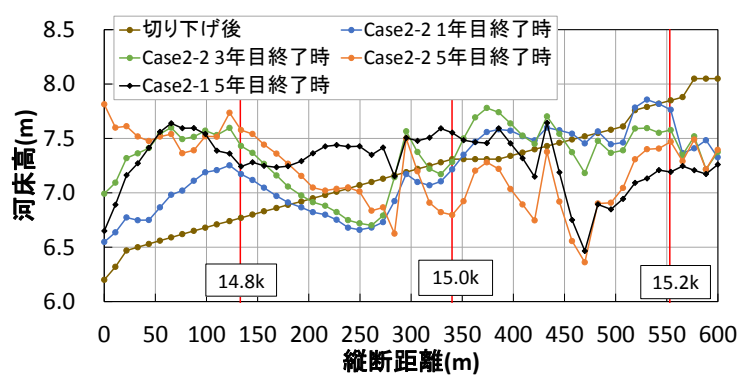

図-10＼cjkstart河床高の経年変化 (縦断ライン)

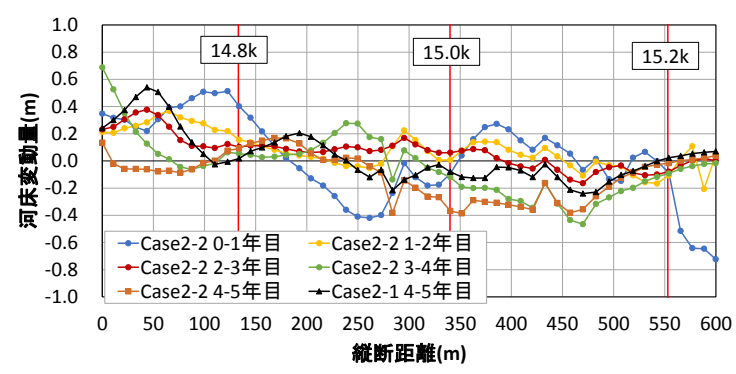

図-11 前年と比較した河床変動量(縱断ライン)

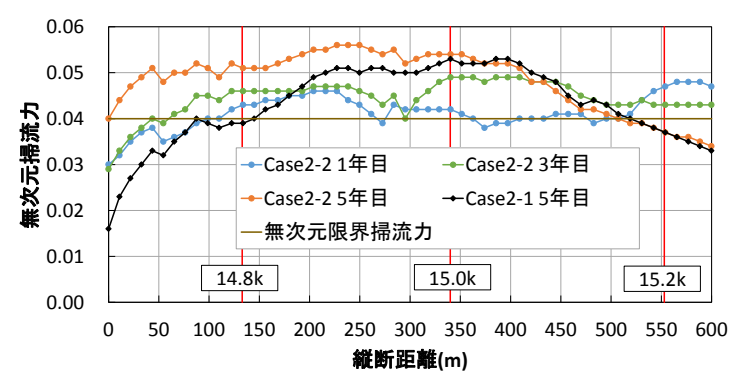

図-12 無次元掃流力の経年変化 (縦断ライン)

しかし，現地において過去 10 年で $2000 \mathrm{~m}^{3} / \mathrm{s}$ 規模洪水 が3回, $3000 \mathrm{~m}^{3} / \mathrm{s}$ 規模洪水が2回発生したことを考慮 すると, $1000 \mathrm{~m}^{3} / \mathrm{s}$ の攪乱の少ない洪水が数年続いた 後に攪乱規模の大きな洪水が発生した場合にどちら が効果があるかを検討することも必要である。そこ で, 5 年目において近年発生した大規模な洪水である 2011年の洪水 (ピーク流量 $3403 \mathrm{~m}^{3} / \mathrm{s}$ ) が発生したと仮 定してCase2-1 とCase2-2で植生の流出の様子を比較 した. 図-15, 図-16に各々洪水後の植生高を示す. この図より, Case2-2の掘削に加えて低水路埋め戻し を実施した場合には図-14で示した15.0km付近の砂 州上で繁茂しかけた植生が流失(オレンジ色破線部) しているだけでなく, 赤色破線部で示すように掘削 路下流端付近や砂州左岸水際においても河床攪乱の 効果により植生が流失し易くなっていることが分か る.これらはいずれも埋戻しによって洪水流が中州 に乗り上げやすくなったことが原因と考えられる.

\section{5. 結論}

本研究では，樹林化を抑制し，自律的に礫河原を 維持，再生させることを目的として旭川祇園地区を 対象に碩河原再生効果の持続性を検討した。得られ た結論を以下に示す。 


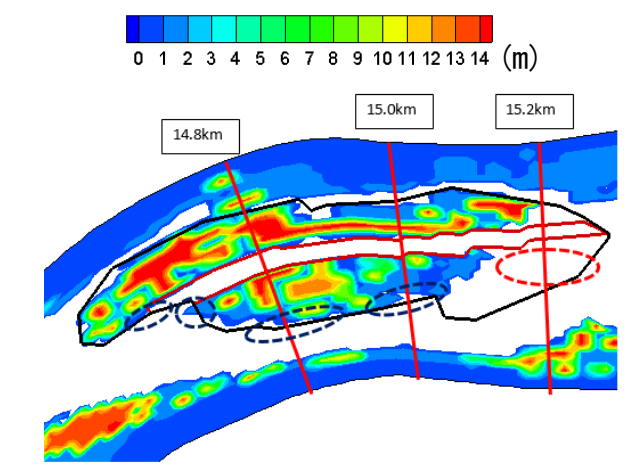

図-13 Case2-1 最終年植生高（赤枠が掘削路）

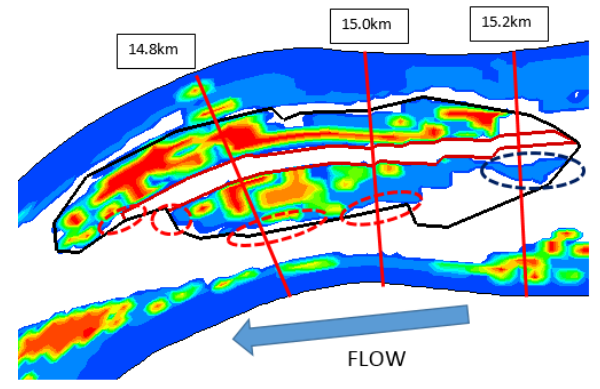

図-14 Case2-2 最終年植生高（赤枠が掘削路）

1) 砂州切り下げを行うことによって掘削路内の無次 元掃流力は増加寸る. また, 切り下げに加えて低水路 の埋戻しを行うことで掘削路の掃流力をさらに増加 させることが分かった。

2) 砂州掘削だけの場合と低水路埋戻しを加えた場合 について年平均最大洪水流量程度が数年続く場合の 植生消長シミュレーションの結果, 若干低水路埋め戻 しをした場合の方が河岸沿いの植生は流失し易くな るが，両者の差は小さいことが分かった。

3) 過去 10 年間で 2 回発生した $3000 \mathrm{~m}^{3} / \mathrm{s}$ 規模洪水が数 年の小規模洪水後に来ることを想定した場合には, 明 らかに切り下げのみよりも埋戻しを同時に行うこと でより植生が流出し易くなることが示された.

謝辞 : 本研究を行うに当たり, 国土交通省中国地方整 備局岡山河川事務所から多数の貴重なデータを頂い た. また, 本研究の一部は文部科学省科学研究費補助 金，基盤研究(B)（題目：河川環境の自律的再生を誘 導寸る河道の維持-改修技術の体系化, 代表者 : 道奥 康治, 課題番号 : 26289164）, 及び若手研究(B)（題 目 : 効率的な河道管理を目指した, 河道内植生の動態 に関する水理学的研究, 代表者:吉田圭介, 課題番号: 26820203)の援助を受けた。記して謝意を表する。

\section{参考文献}

1) 渡辺敏, 前野詩朗, 藤塚佳晃, 宮崎貢, 眞田淳二 : 旭川 における礫河原再生と樹林化抑制に関する現地試験に よる検証, 水工学論文集, 第50巻, pp.1201-1206, 2006.

2) 増子輝明, 前村良雄, 森川陽一, 後藤勝洋: 鬼怒川中流 部における碟河原再生について, リバーフロント研究所 報告，第21号，pp.9-18，2010.

3) 鈴木良徳, 平野寿謙, 北村聡 : 河川営力を活用した加古 川における樹林化抑制対策とその効果と課題, (一社)建

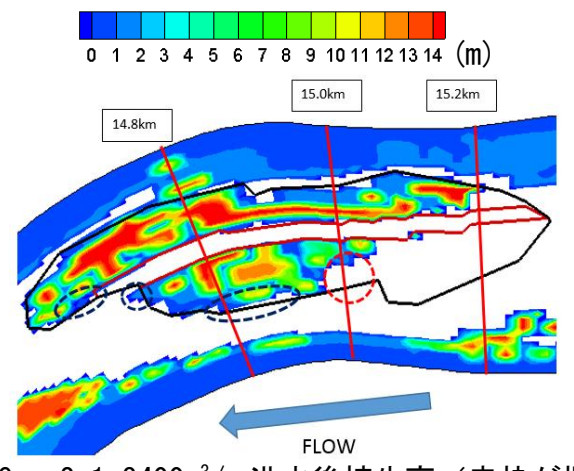

図-15 Case2-1 $3400 \mathrm{~m}^{3} / \mathrm{s}$ 洪水後植生高（赤枠が掘削路）

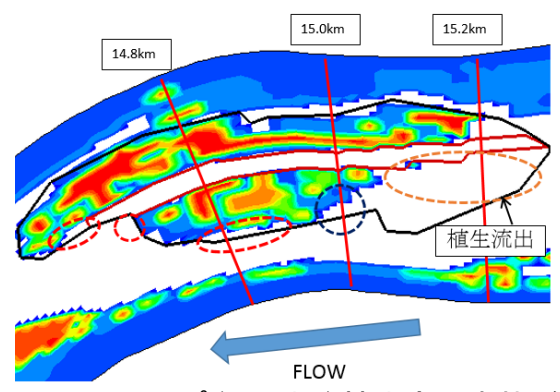

図-16 Case2-2 $3400 \mathrm{~m}^{3} / \mathrm{s}$ 洪水後植生高（赤枠が掘削路）

設コンサルタンツ協会近畿支部研究発表会, 第47回, 2014.

4) 阿河一穂, 道奥康治, 神田佳一, 魚谷拓矢 : 河道の経年 変化から見た樹林化の要因分析と持続的な河川管理の ための方策, 土木学会論文集B1 (水工学), Vol68, No.4, pp.I_745-I_750, 2012.

5）長田健吾, 演井宣明, 青木朋也, 藤本雅信, 嘉田功, 川 田健人: 交互砂州河道における効率的な植生管理策に関 寸る研究，河川技術論文集，第20巻，pp.181-186， 2014.

6) 八木澤順治，田中規夫 : 砂礫州切り下げ後の長期植生動 態解析に基づく樹林化抑制効果の確率論的検討, 河川技 術論文集，第21巻，pp.319-324，2015.

7) 渡邊明英, 福岡捷二, 安竹悠, 川口広司 : 河道湾曲部に おける河床変動を抑制する樹木群水制の配置方法, 河川 技術論文集，第7巻，pp.285-290，2001.

8) 関根正人：移動床流れの水理学, 共立出版株式会社 p.161, 2005.

9) 前野詩朗, 吉田圭介, 松山悟, 藤田駿佑 : 旭川大原試験 区における植生消長シミュレーションモデルの構築と 検証，土木学会論文集B1 (水工学), Vol.70, No.4, pp. I_1369-I_1374, 2014.

10) 末次忠司, 藤田光一, 服部敦 : 流れによる変形を考慮し た高茎草本植物の抵抗性，国土技術政策総合研究所資 料, No.158, 2004.

11) 前野詩朗, 渡辺敏, 藤塚佳晃 : 簡易に得られる植物特性 值を考慮した数值解析モデルの精度向上の提案, 土木学 会論文集，No.803／II -73，pp.91-104，2005.

12) 椿東一郎, 荒木正夫 : 水理学演習下巻 11 版, 森北出版 pp.7-10, 1995.

13) 吉田圭介, 前野詩朗, 藤田駿佑, 松山悟, 岩城智大, 平 井康隆:旭川における植生分布の経年変化を考慮した洪 水流の数值解析, 土木学会論文集B1(水工学), Vol.71, No.4, pp. I_1039-I_1044, 2015.

14) 田中規夫，八木澤順治，佐々木寧，福岡捷二 : 河道内樹 木の洪水破壊形態と破壊限界值の基盤土䁃条件による 相違, 水工学論文集, 第52巻, pp.649-654, 2008.

(2015. 9. 30受付) 